\title{
PEMILIHAN TAPAK ALTERNATIF BAGI PENGEMBANGAN KANTOR KECAMATAN WINDUSARI
}

\author{
Arnis Rochma Harani ${ }^{1}$ ), Eddy Indarto $^{2}$ ), Resza Riskiyanto ${ }^{1}$ ), M.Najieb Sholih ${ }^{3}$ ) \\ *) Corresponding author email : arnisrochma@arsitektur.undip.ac.id \\ 1) Departemen Arsitektur, Fakultas Teknik, Universitas Indonesia, Depok-Indonesia \\ 2) Departemen Arsitektur, Fakultas Teknik, Universitas Diponegoro, Semarang - Indonesia \\ 3) CV. Realine Design Lab, Semarang - Indonesia
}

\author{
Article info \\ MODUL vol 19 no 2, issues period 2019 \\ Doi $\quad: 10.14710 / \mathrm{mdl} .19 .2 .2019 .95-103$ \\ Received : 20th october 2019 \\ Revised : 4th november 2019 \\ Accepted : 15th november 2019
}

\begin{abstract}
Kawasan kecamatan di Indonesia pada saat ini harus maтри mewadahi kegiatan masyarakat tingkat kecamatan tersebut, baik itu formal dan informal. Kebutuhan ruangan dan kelayakan tapak untuk kantor kecamatan mengalami tren yang meningkat. Sehingga bangunan saat iniyang hanya mampu menampung kegiatan-kegiatan bagi staffnya dan ruang yang sudah ada, harus dikembangkan agar dapat menampung masyarakat. Kebencanaan juga berkembang dalam kondisi Indonesia yang terletak pada lingkaran gunung api (ring of fire). Berbagai masalah yang timbul di lokasi memerlukan suatu studi untuk mengetahui kecamatan untuk dapat dikembangkan. Studi berlangsung dengan paradigma kuantitatif dengan pendekatan deduktif melalui analisis pustaka, studi observasi lapangan dan studi kasus kecamatan. Tujuan dari studi ini adalah untuk menentukan kelaikan tapak yang sedang digunakan sebagai kantor kecamatan. Hasil dari studi ini menemukan bahwa tapak eksisting masih layak untuk dikembangkan.
\end{abstract}

Keywords: studi evaluasi; analisa tapak; kantor kecamatan; kebencanaan

\section{PENDAHULUAN}

Kecamatan Windusari adalah salah satu kecamatan di kabupaten Magelang yang berjarak $25 \mathrm{Km}$ dari Kota Magelang. Pusat pemerintahannya berada di Desa Windusari. Kecamatan Windusari berada di lereng Gunung Sumbing, dengan ketinggian rata-rata wilayahnya $525 \mathrm{mdpl}$. Mayoritas penduduknya bekerja sebagai petani, yaitu petani tembakau dan petani sayur- mayur. Saat ini Kantor kecamatan Windusari berada di jalan Kaliangkrik Windusari.

Menurut Peraturan Presiden Republik Indonesia Nomor 73 Tahun 2011 Pasal 5 Tentang Pembangunan Bangunan Gedung Negara klasifikasi bangunan, bangunan kecamatan dapat diklasifikasikan kedalam bangunan sederhana. Ada beberapa spesifikas yang arus diprhatikan ketika membangun bangunan pemerintah dalam klasifikasi bangunan sederana.

Seiring berkembangnya penataan Kawasan di Indonesia, maka bangunan kecamatan saat ini harus mampu menjadi wadah bagi kegiatan masyaakat baik secara formal maupun informal. DEngan demikian dibutuhkan suatu kantor kecamatan denganluasan tertentu yang dapat menjadi wadah bagimasyarakat untuk berkumpul, melakukan aktifitas komunal serta menjadi sebuah pusat pemerintaha skala kecamatan.

Saat ini kondisi kantor kecamatan windusari berada di jalanan yang memiliki kontur cukup ekstrim, yaitu akses pintu masuk kecamatan berada di jalan tanjakan, sehingga membahayakan dari segi pencapaian, memngingat bangunan kecamatan merupakan bangunan pelayanan public yang harus memperhatikan factor tersebut. Selain itu dalam perkembangannya kebutuhan ruangan untuk kecamatan semakin meningkat, sedangkan bangunan saat ini hanya mampu menampung kegiatan-kegiatan bagi staffnya. Ruang pelayanan belum optimal.

Dari berbagai permasalahan yang ada di lokasi, maka dibutuhkan suatu studi untuk mengetahui kelayakan bangunan kecamatan untuk di kembangkan, baik itu di relokasi atau dikembangkan kembali. Studi kelayakan ini akan membahan mengenai kelebihan dan kekurangan serta pembobotan tapak yang akan digunakan sebagai penentu pengambilan keputusan dalam mengembangkan kantor kecamatan Windusari..

\section{METODE}

Studi ini menggunakan paradigma kuantitatif dengan pendekatan deduktif. Studi ini termasuk bagian 
dari penelitian universal desain yang berkaitan dengan prinsip adaptabilitas tanpa mengesampingkan prinsip aksesibilitas, suportif dan keamanan (Aslaksen, 1997). Studi tentang desain dapat dilakukan dengan : evaluasi dari peraturan yang berlaku, dan pendalaman terhadap studi yang sudah ada (Harsritanto, 2018).. Studi ini termasuk pada evaluasi dari peraturan yang berlaku. Studi literatur, observasi tapak dan studi kasus yang cocok untuk mengevaluasi suatu keadaan digunakan untuk mendukung penelitian ini (Harsritanto et al, 2017 dan Dumanski, 1997). Studi literatur tentang regulasi dan pustaka terkait analisa tapak menjadi acuan dalam pendalaman kerangka evaluasi untuk diujikan pada objek studi. Observasi tapak digunakan untuk mendapatkan nilai kelaikan tapak berdasarkan rumusan parameter dari studi literatur sebelumnya. Studi kasus digunakan untuk memaknai luaran dari evaluasi observasi tapak eksisting (Harsritanto, 2018).

Waktu penelitian ini dilakukan pada rentang waktu 3 bulan dan dilakukan melalui empat tahapan utama, yaitu :

a) Tahap Persiapan

Tahapan ini mengkaji pustaka dan regulasi terkait pembangunan kantor kecamatan beserta penelitian awal tentang lokasi.

- Melaksanakan observasi awal guna mendapatkan gambaran awal mengenai keadaan kantor kecamatan eksisting

- Menyusun kajian literatur dan regulasi yang berhubungan dengan aspek-aspek pembangunan kantor kecamatan

- Menentukan acuan yang dijadikan sebagai pegangan dalam mencari data

b) Tahap Pengumpulan data

Metode pengumpulan data adalah bagian instrumen pengumpulan data yang menentukan berhasil atau tidaknya suatu penelitian (Bungin, 2005). Sehingga perlunya tahap persiapan yang kuat literatur dan peraturannya.

- Melaksanakan observasi dengan cara langsung dan tidak langsung.

- Melakukan kompilasi data untuk selanjutnya diolah menggunakan metode statistic guna menyusun analisis.

- Menyusun data-data terkait scoring

c) Tahap Analisis, Pembahasan, dan Pemaknaan

- Membaca hasil pengolahan data untuk melakukan analisis dan pembahasan tentang aspek-aspek yang diteliti dalam penelitian

- Menyusun hasil analisis tersebut sebagai suatu kajian penelitian

d) Tahap penarikan kesimpulan dan rekomendasi
- Penarikan kesimpulan sebagai hasil kajian pada analisis dan pembahasan

- Penyusunan rekomendasi yang didasarkan pada temuan hasil penelitian.

Penentuan variabel didapat dari studi kelayakan sebelumnya yaitu : keadaan geografis, eksisting, lokasi, dan fasilitas penunjang (Harani et al, 2019) yang diturunkan dari kajian faktor penentuan lokasi lokasi (Vera Sari, 1997), standar kantor pemerintahan (Sujarto,1985) (Sujarto,2001) dengan dimensi sosial dan fisik (Pray, 1914) pada pencapaian (Hakim \& Cahyana, 2015) dan potensi konektivitasnya dengan sekitar (Chiara \& Hancock,2001)

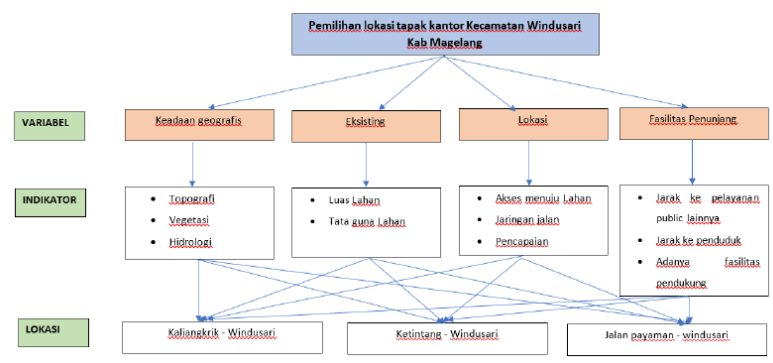

Gambar 1: Skema evaluasi tapak untuk pengembangan

kantor kecamatan Windusari

Dalam proses penilaian guna memilih lokasi tapak kantor kecamatan Windusari yang baru, yang akan digunakan sebagai variabel, indicator seperti yang tercantum di gambar 1 . Ada 3 lokasi tapak yang menjadi alternative, yaitu Kaliangklik tepat di belakang kantor kecamatan eksisting, pilihan kedua daerah Ketintang dan alternative ketiga ada di jalan Banjarsari.

\section{ANALISA DAN PEMBAHASAN}

Analisa kondisi tapak eksisting kecamatan Windusari

Kabupaten Magelang merupakan salah satu Kabupaten yang terletak di tengah area Provinsi Jawa Tengah dengan luas wilayah $1.085,73 \mathrm{~km} 2$. Wilayah Kabupaten Magelang terkenal dengan pariwisatanya yang sangat beragam mulai dari wisata buatan, budaya, alam, religi, dan sebagainya. Kabupaten Magelang berdasarkan letak geografis berada di bagian tengah dari Provinsi Jawa Tengah yaitu antara :

- Bujur Timur : 110o01'51' dan 110o26'58'

- Lintang Selatan : 7o19'13" dan 7o42'16"

Sedangkan batas wilayah dengan daerah lain adalah sebagai berikut :

- Sebelah Utara : Kabupaten Temanggung dan Kabupaten Semarang

- Sebelah Timur : Kabupaten Semarang dan Kabupaten Boyolali 
- Sebelah Selatan : Kabupaten Purworejo dan Wilayah D.I.Y.

- Sebelah Barat : Kabupaten Temanggung dan Kabupaten Wonosobo.

- Di Tengah : Kota Magelang

Secara adminstratif Kabupaten Magelang terbagi menjadi 21 kecamatan, 372 desa/kelurahan. Berikut prosentase luas wilayah masing-masing kecamatan di wilayah Kabupaten Magelang (gambar 2).

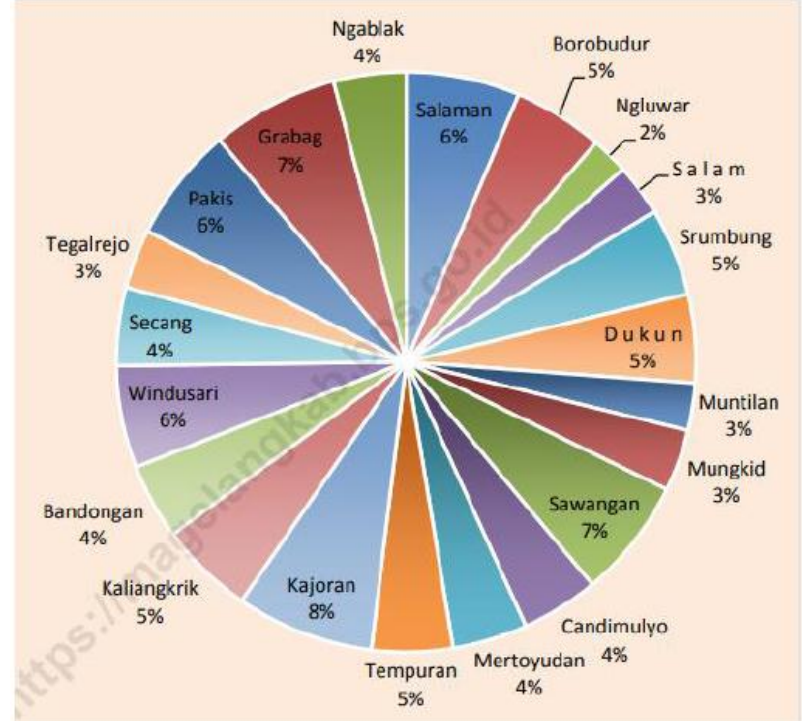

Gambar 2: Diagram pie luasan kecamatan di Magelang

Lokasi Kantor kecamatan Windusari terletak 350 meter dari pusat kegiatan di kecamatan windusari. Terletak persis disebrang SMP Negeri 1 Windusari dan berada satu kavling dengan kantor pos Windusari serta Balai Pelayanan KB-KS Kecamatan Windusari. Lokasinya berada pada jalan yang berkontur dengan akses yang sulit karena berada dijalan tanjakan terjal. Namun Memiliki akses pencapaian langsung dari jalan raya (lihat gambar 3 ).
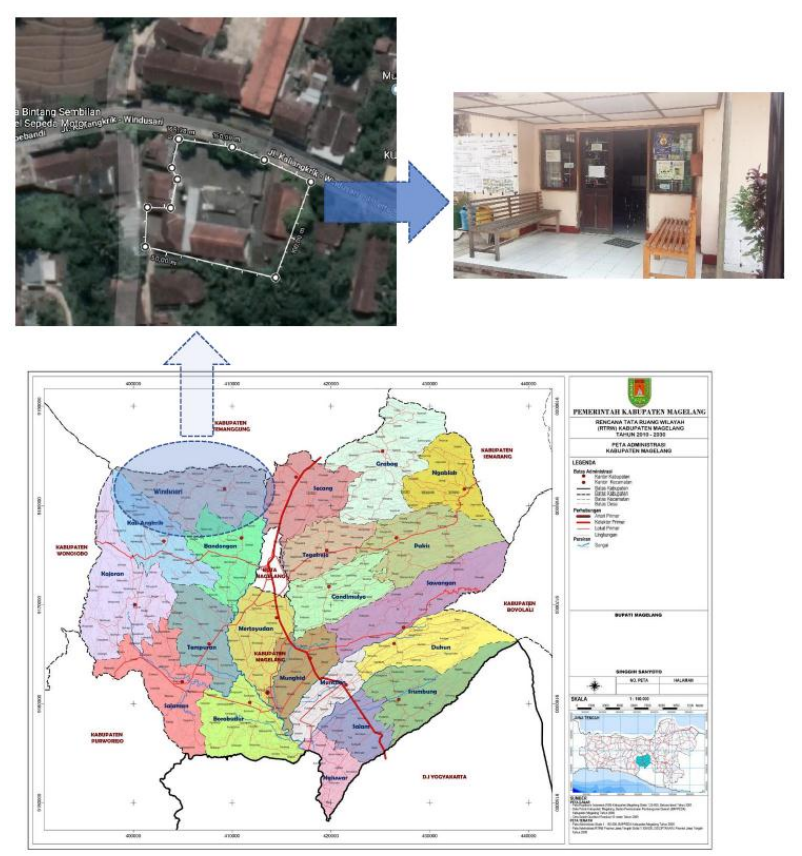

Gambar 2: Lokasi eksisting kantor kecamatan Windusari

Kondisi luasan kantor yang $1600 \mathrm{~m} 2$ sedangkan berdasarkan Peraturan Pemerintah Daerah Kabupaten Magelang No.2 Tahun 2015 bangunan perkantoran dan pelayanan umum memiliki persyaratan KDB $60 \%$. Sehingga dengan kebutuhan ruang $1200 \mathrm{~m}^{2}$ luas lahan Kantor Kecamatan Windusari tidak mampu memenuhi kebutuhan tersebut $\left(60 \%\right.$ dari $1600 \mathrm{~m}^{2}$ adalah $\left.960 \mathrm{~m}^{2}\right)$. Maka dari itu sangat dibutuhkan pemindahan lokasi Kantor Kecamatan Windusari ke lokasi yang memadai dengan minimal luasan $2000 \mathrm{~m}^{2}$.

Kajian letak/lokasi eksisting kantor kecamatan windusari adalah sebagai berikut :

- Topografi Kondisi topografi di kantor kecamatan windusari saat ini, sangat berkontur, berada tepat di kontur yang terjal dan cukup ekstrim di tiap konturnya. ]

- Vegetasi Kondisi vegetasi kantor kecamatan windusari saat ini, tidak terdapat vegetasi sama sekali, karena sudah full bangunan. Bahkan KDH 0\% yang tidak sesuai dengan peraturan pemerintah.

- Hidrologi Hidrologi cukup baik karena berada diarea yang tinggi. Air cukup jernih dan menggunakan sumur

- Luas Lahan Lahan seluas 1600 meter namun berada satu kavling dengan Kantor Pos Windu sari dan Balai Pelayanan KB-KS Kecamatan Windusari.

- Tata guna Lahan Fungsi guna bangunan sebagai area perkantoran. Sudah sesuai dengan peraturan

- Akses menuju Lahan Akses menuju lokasi dapat secara langsung dari jalan raya namun berada dijalan tanjakan, sehingga sangat berbahaya dan menyulitkan akses masuk 
- Jaringan jalan Terdapat jalan utama tepat didepan kantor kecamatan windusari

- Pencapaian Pencapaian secara langsung dari jalan utama

- Jarak ke pelayanan public lainnya Jarak ke pelayanan public lainnya antara 50 meter sampai $1 \mathrm{KM}$

- Jarak ke penduduk Berada dekat dengan permukiman penduduk

- Fasilitas pendukung ada dan dekat dengan lokasi

Kondisi eksisting tapak tersebut setelah disesuaikan dengan evaluasi tapak, didapat hasil penilaian tapak eksisting dengan nilai total 27 dari 55 (lihat tabel 1).

Tabel 1: Tabel Perhitungan penilaian tapak eksisting

\begin{tabular}{|l|l|l|c|}
\hline No & \multicolumn{1}{|c|}{ Indikator } & \multicolumn{1}{|c|}{ Variabel } & $\begin{array}{c}\text { Score } \\
(1-5)\end{array}$ \\
\hline 1 & $\begin{array}{l}\text { Keadaan } \\
\text { geografis }\end{array}$ & Topografi & 2 \\
\hline & & Vegetasi & 3 \\
\hline 2 & Eksisting & Hidrologi & 3 \\
\hline & & Tata guna Lahan & 1 \\
\hline 3 & Lokasi & Akses menuju Lahan & 1 \\
\hline & & Jaringan jalan & 1 \\
\hline & & Pencapaian & 4 \\
\hline 4 & Fasilitas & $\begin{array}{l}\text { Jarak ke pelayanan public } \\
\text { lainnya }\end{array}$ & 4 \\
\hline & & Jarak ke penduduk & 4 \\
\hline & & Adanya fasilitas pendukung & 4 \\
\hline
\end{tabular}

Jika dilihat dari data diatas maka lokasi kantor kecamatan sebenarnya sudah memenuhi persyaratan, namun ada beberapa aspek yang tidak memungkinkan untuk dibenahi ketika dikembangkan bangunan kecamatan baru. Contohnya luas lahan, akses/pencapaian dan topografi, sehingga diperlukan beberapa alternative tapak untuk membangun kantor kecamatan windusari yang baru. Dari Nilai terbesar 5 dan terendah 1 didapatkan jumlah score maksimal 55, pada scoring yang dilakukan untuk lokasi eksisting kantor kecamatan windusari didapatkan score 39, hanya $70 \%$ nya saja. Padahal untuk mendapatkan score ideal dibutuhkan $80 \%$ minimal untuk kategori layak. Jika demikian maka $70 \%$ dianggap belum layak untuk dikembangkan lebih lanjut. Dari indicator penilaian (scoring) maka 70\% termasuk layak namun kurang ideal

\section{Analisa kondisi tapak alternatif 1 Kaliangkrik}

Alternatif tapak yang pertama berada tepat di Kaliangkrik yang terletak di belakang kantor Kecamatan Windusari yang telah terbangun. Tapak memiliki luas : : + $7400 \mathrm{~m} 2$, dengan batas Utara : Kantor kecamatan Windusari (eksisting), Timur : Area
Perkebunan, Selatan : Area Perkebunan, Barat : Area Perkebunan (lihat gambar 2)
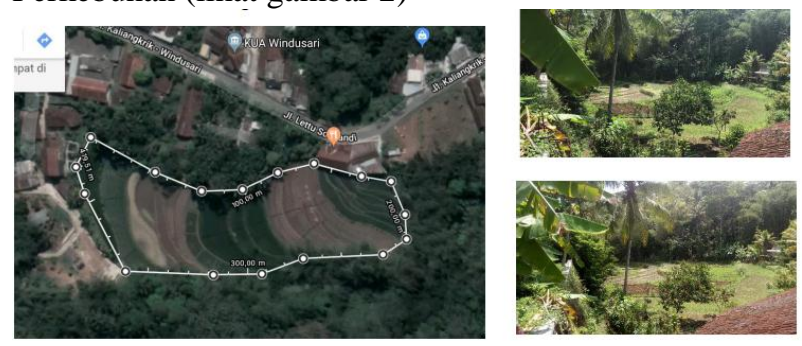

Gambar 2: letak dan kondisi lahan Kaliangkrik

Alternatif Tapak ini memiliki topografi yang miring ke arah timur dan berada berada pada ketinggian 632-648 meter di atas permukaan laut. Berada pada area persawahan yang memiliki jenis tanah gambur dan sudah terdapat terasering (lihat gambar 3). Kemiringan antara $30-50$ derajat sehingga membuat lahan sangat bertransis. Model tapak seperti ini memiliki kesulitan dalam pengelolaan tahan sebagai kantor, dikarenakan kantor kecamatan merupakan pelayanan masyarakat yang baiknya memiliki desain yang universal, sehingga semua kalangan baik dari usia muda hingga tua dan dari orang normal hingga difable dapat menggunakan kantor pelayanan ini.

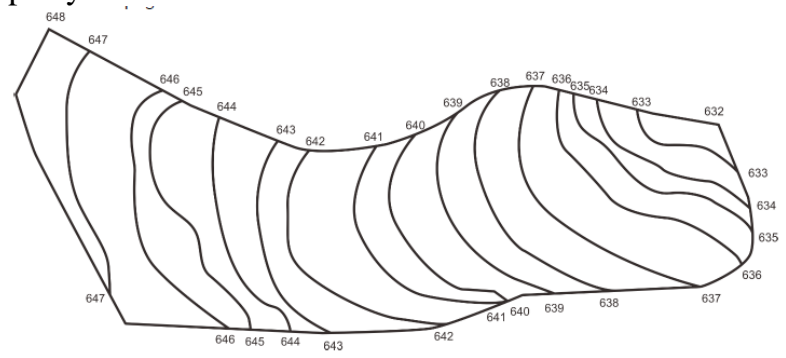

Gambar 3: Topografi lahan Kaliangkrik

Pada alternative tapak ini terdapat beberapa vegetasi namun masih memungkinkan untuk diolah, vegetasi yang terdapat pada tapak beracam, antara lain :

- Pohon Pisang (Musa acuminata, M. balbisiana, dan M. ×paradisiaca)

- Padi (Oryza sativa L.)

- Pohon kelapa (Cocos nucifera)

Alternatif tapak ini berada di belakang kantor kecamatan Windusari saat ini, air yang digunakan merupakan sumur dalam sehingga hidrologi pada tapak ini dimungkinkan sama dengan kantor kecamatan eksisting.

Luas Lahan Luas lahan yang ideal untuk perkantoran pemerintah dan bangunan Gedung pemerintah adalah 1.250 meter sesuai dengan Peraturan Presiden Republik Indonesia Nomor 73 Tahun 2011 Pasal 5 Tentang Pembangunan Bangunan Gedung Negara, pada peraturan dituliskan bangunan minimal 500 meter dengan asumsi KLB $60 \%$ sesuai dengan aturan setempat, sehingga didapatkan luasan minimal 
lahan adalah 1.250 meter. Pada alternative tapak ini, luasan lahannya sangat besar, yaitu 7.400 meter sehingga memenuhi untuk dijadikan bangunan kantor kecamatan.

Tata guna Lahan Tata guna lahan pada alternative tapak ini adalah sebagai persawahan dan perkebunan, dibuktikan dengan masih aktifnya lahan untuk fungsi tersebut. Namun bila dilihat secara Kawasan maka tata guna lahannya berdekatan dengan perkantoran, sehingga masih memungkinkan digunakan sebagai perkantoran.

Alternatif tapak ini tidak terdapat akses jalan secara langsung, kecuali pembongkaran kantor kecamatan Windusari eksisting. Sehingga akses dapat dilakukan melalui tapak tersebut. Jaringan jalan pada lokasi ini tidak ada, jika dikembangkan kemudian haripun sulit karena tapak berada di layer kedua jalan raya (jalan utama kecamatan windusari). Sama dengan jaingan jalan, pencapaian pada tapak ini tidak hanya tidak bisa secara langsung tapi tidak ada sama sekali.

Pada alternatif tapak ini, jrak menuju pelayanan public lainnya sangat dekat karena berada tepat dibelakang Kantor Pos Windusari dan Balai Pelayanan KB-KS Kecamatan Windusari serta hanya berjarak kurang dari $1 \mathrm{KM}$ dari SMP N 1 Windusari. Sehingga dapat dikatakan alternative tapak ini sangat baik dari segi jarak pelayanan publiknya. Tapak ini berada dekat dengan permukiman warga, hanya sekitar kurang dari 1 KM dari permukiman warga, sehingga jika dilihat dari fungsi bangunannya sebagai bangunan pelayanan pemerintah serta pusat pemerintahan skala kecamatan lokasi ini tepat digunakan. fasilitas pendukung, seperti kantor pos karena lokasinya berada tepat dibelakang kantor kecamatan eksisting. Namun diarea tapaknya tidak terdapat fasilitas pendukung, karena masih berupa lahan persawahan.

Kondisi tapak Kaliangkrik tersebut setelah dinilai dengan evaluasi tapak, didapat hasil penilaian tapak eksisting dengan nilai total 27 dari 50 (lihat tabel 2). Hasil tersebut sama dengan hasil eksisting kecamatan karena lokasinya yang berada dibelakang persis tapak yang sekarang.

Tabel 2: Tabel Perhitungan penilaian tapak 1

\begin{tabular}{|l|l|l|c|}
\hline No & \multicolumn{1}{|c|}{ Indikator } & \multicolumn{1}{|c|}{ Variabel } & $\begin{array}{c}\text { Score } \\
(\mathbf{1 - 5})\end{array}$ \\
\hline 1 & $\begin{array}{l}\text { Keadaan } \\
\text { geografis }\end{array}$ & Topografi & 2 \\
\hline & & Vegetasi & 3 \\
\hline 2 & Eksisting & Hidrologi & 1 \\
\hline & & Tata guna Lahan & 2 \\
\hline 3 & Lokasi & Akses menuju Lahan & 1 \\
\hline & & Jaringan jalan & 1 \\
\hline & & Pencapaian & 4 \\
\hline 4 & Fasilitas & $\begin{array}{l}\text { Jarak ke pelayanan public } \\
\text { lainnya }\end{array}$ & \multicolumn{2}{|c}{} \\
\hline
\end{tabular}

\begin{tabular}{|l|l|l|c|}
\hline & & Jarak ke penduduk & 5 \\
\hline & & Adanya fasilitas pendukung & 4 \\
\hline
\end{tabular}

Dari tabel 2 diatas didapatkan hasil score sejumlah 27 dari nilai maksimal 55, dapat di prosentasikan yaitu sebesar $49 \%$ hasilnya. Jika dilihat dengan prosentase scoring yang sudah ditentukan diatas, hasil scoring yaitu $49 \%$ yang berarti sangat tidak layak.

\section{Analisa kondisi tapak alternatif 2 Ketintang}

Alternatif tapak yang kedua berada 500m dari pusat keramaian Kecamatan Windusari yaitu Ketintang. Tapak ini terletak di tengah perkebunan ubi, kentang dan padi. Tapak tersebut berdekatan dengan rencana pembangunan pasar Windusari yang baru. Tapak yang terletak di lahan terasering ini memiliki potensi wisata dan berbatasan dengan perkebunan dan memiliki luas $8400 \mathrm{~m}^{2}$ (lihat gambar 4).
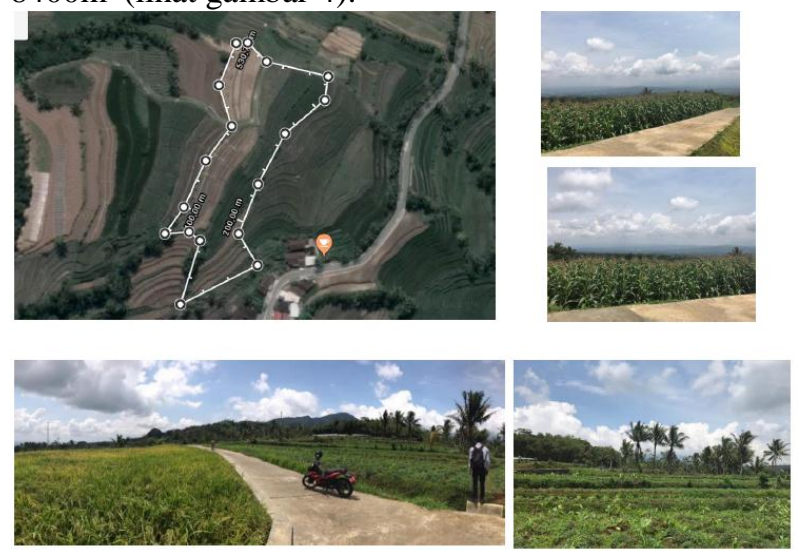

Gambar 4: letak dan kondisi lahan Ketintang

Alternatif Tapak ini memiliki topografi yang miring ke arah timur dan berada berada pada ketinggian 602-598 meter di atas permukaan laut. Berada pada area persawahan yang memiliki jenis tanah gambur dan sudah terdapat terasering. Kemiringan antara $30-50$ derajat sehingga membuat lahan bertransis. Model tapak pada alternative ini adalah transis dengan lebar antara 510 meter, sehingga memiliki kemungkinan pengolahan lahan secara maksimal (lihat gambar 5). Yaitu dibuat transis di dalam kantornya. Hal lain adalah tapak ini dipisahkan atau dibelah oleh jalan sehingga tidak memungkinkan memiliki satu Kawasan utuh. Jika nantinya dibangun kantor maka aka nada zona-zona yang terpisah berdasarkan fungsi. Karena jalan yang membelahnya tidak mungkin ditutup. Atau bisa jadi alternative lain adalah memilih lahan yang hanya disatu sisi saja hal ini dirasa lebih masuk akal. 


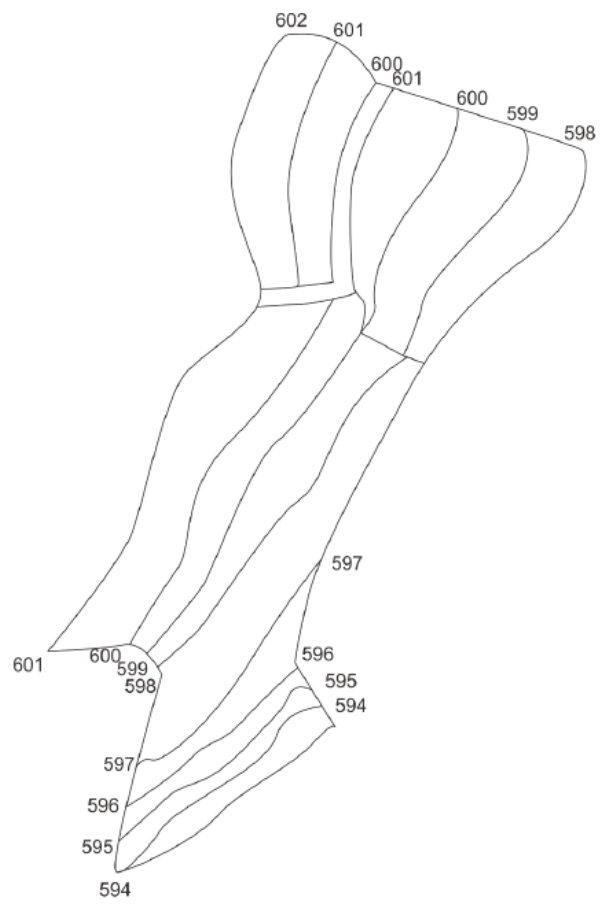

Gambar 5: Topografi lahan Ketintang

Pada alternative tapak ini terdapat beberapa vegetasi namun masih memungkinkan untuk diolah, vegetasi yang terdapat pada tapak beracam, antara lain :

- Pohon Pisang (Musa acuminata, M. balbisiana, dan M. ×paradisiaca)

- $\quad$ Padi (Oryza sativa L.)

- Pohon kelapa (Cocos nucifera)

- Ubi jalar (Ipomoea batatas L.)

- Jagung (Zea mays)

Pada alternative tapak ini, terdapat mata air (sumber air) yang alami, saat ini digunakan sebagai pengairan kebun dan sawah. Hal ini sangat baik jika didirikan kantor kecamatan, karena pasti akan mudahmendapatkan air. Namun belum terdapat pembuangan air lingkungan. Jarak kepembuangan air cukup jauh sekitar 50 meter.

Luas lahan yang ideal untuk perkantoran pemerintah dan bangunan Gedung pemerintah adalah 1.250 meter sesuai dengan Peraturan Presiden Republik Indonesia Nomor 73 Tahun 2011 Pasal 5 Tentang Pembangunan Bangunan Gedung Negara, pada peraturan dituliskan bangunan minimal 500 meter dengan asumsi KLB 60\% sesuai dengan aturan setempat, sehingga didapatkan luasan minimal lahan adalah 1.250 meter. Pada alternative tapak ini, luasan lahannya sangat besar, yaitu 8.400 meter sehingga sangat memenuhi untuk dijadikan bangunan kantor kecamatan. Bahkan jika dilengkapi dengan beberapa fasilitas ruang terbuka public karena lokasinya memiliki view yang sangat bagus (lihat gambar 6).
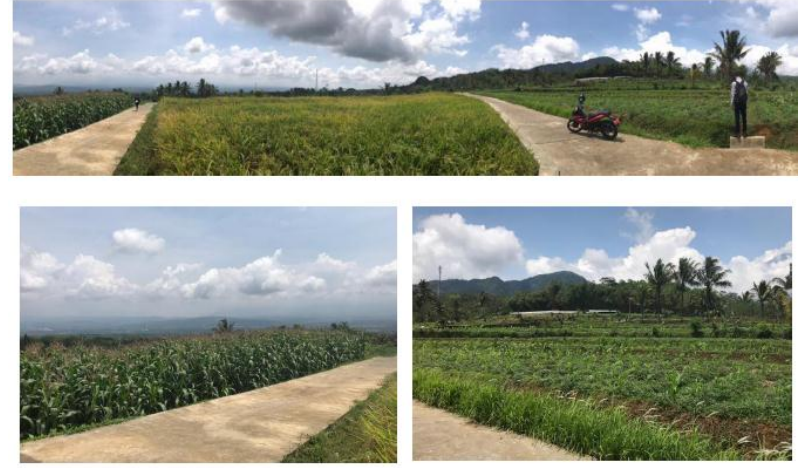

Gambar 6: View lahan Ketintang

View yang ada pada tapak sangat bagus dan bias menjadi unggulan alternative tapak ini, karena dari lokasi dapat melihat gunung sindoro, sumbing dan gunung menoreh. Serta terpampang pemandangan kota magelang secara jelas tanpa terhalang oleh bangunan apapun.

Tata guna lahan pada alternative tapak ini adalah sebagai perkebunan, dibuktikan dengan masih aktifnya lahan untuk fungsi tersebut. Namun bila dilihat secara Kawasan maka tata guna lahannya berdekatan dengan pengembangan pasar, sehingga masih memungkinkan digunakan sebagai perkantoran.

Akses menuju jalan bias dicapai secara tidak langsung, yang berarti lahan berada tidak tepat ditepi jalan raya, namun harus masuk melalui jalan yang terjal, sehingga akses tersebut agak menyulitkan. Dan secara visual bangunan tidak bias langsung terlihat. Jaringan jalan pada alternative tapak ini adalah jalan lingkungan dengan lebar jalan hanya 2 meter dan sangat terjal. Hal ini sangat menyulitkan jika ada mobil yang ingin menuju lokasi, kecuali dengan pelebaran jalan. Serta jika dilakukan pembangunan maka transportasi bahan bangunan akan sulit sampai di lokasi. Karena truk tidak dapat sampai dilokasi. Pencapaiak pada tapak tidak langsung dan harus melalui jalan lingkungan. Tidak pula dari jalan raya utama windusari. Sehingga ada dua jaringan jalan yang harus dilalui.

Pada alternative tapak ini, jarak ke pelayanan public lainnya sekitar $2-5 \mathrm{KM}$, namun dalam jangka kedepan akan dibangun pasar tepat disisi sebelah tapak, sehingga kemungkinan berkembangnya fasilitas lainnya masih memungkinkan. Tapak ini berada dekat dengan permukiman warga, hanya sekitar kurang dari 2-5 KM dari permukiman warga, sehingga jika dilihat dari fungsi bangunannya sebagai bangunan pelayanan pemerintah serta pusat pemerintahan skala kecamatan lokasi ini relative jauh dari permukiman. Pada alternative tapak ini tidak terdapat fasilitas pendukung, hanya baru ada rencana akan dikembangkan pasar disebelah tapak ini. Untuk ke fasilitas yang sudah ada jaraknya antara $1-2$ KM. 
Deskripsi diatas didapatkan hasil score sejumlah 37 dari nilai maksimal 55, dapat di prosentasikan yaitu sebesar $67 \%$ hasilnya. Jika dilihat dengan prosentase scoring yang sudah ditentukan diatas, hasil scoring yaitu $67 \%$ yang berarti sangat cukup. Hasil secara keseluruhan cukup dapat diinterpertasikan alternative tapak ini cukup layak namun belum memenuhi score kategori layak (lihat tabel 3)

Tabel 3: Tabel Perhitungan penilaian tapak 2

\begin{tabular}{|l|l|l|c|}
\hline No & \multicolumn{1}{|c|}{ Indikator } & \multicolumn{1}{|c|}{ Variabel } & $\begin{array}{c}\text { Score } \\
(\mathbf{1 - 5})\end{array}$ \\
\hline 1 & $\begin{array}{l}\text { Keadaan } \\
\text { geografis }\end{array}$ & Topografi & 2 \\
\hline & & Vegetasi & 3 \\
\hline 2 & Eksisting & Lidrologi & 5 \\
\hline & & Tata guna Lahan & 3 \\
\hline 3 & Lokasi & Akses menuju Lahan & 4 \\
\hline & & Jaringan jalan & 2 \\
\hline & & Pencapaian & 3 \\
\hline 4 & Fasilitas & $\begin{array}{l}\text { Jarak ke pelayanan public } \\
\text { lainnya }\end{array}$ & 3 \\
\hline & & Jarak ke penduduk & 3 \\
\hline & & Adanya fasilitas pendukung & 3 \\
\hline
\end{tabular}

\section{Analisa kondisi tapak alternatif 3 Banjarsari}

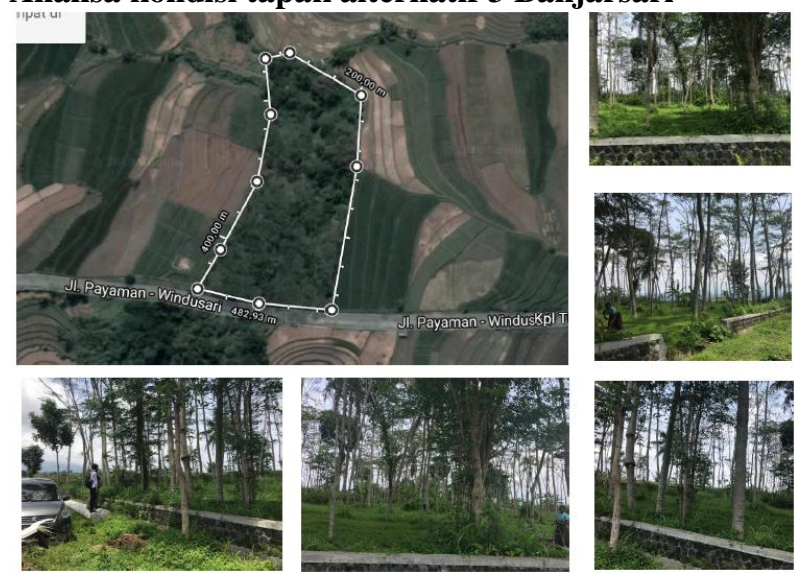

Gambar 7: letak dan kondisi lahan Banjarsari

Tapak ke tiga berada cukup jauh dari kantor kecamatan sebelumnya yaitu $+1,8 \mathrm{KM}$. Tapak yang memanjang kebelakang ini merupakan kebun pohon sengon yang berkontur landau. Tapak ini juga merupakan tapak terluas dari dua tapak sebelumnya (lihat gambar 7). Lokasi tapak tergolong sepi karna jauh dari rumah penduduk dan pusat keramaian namun ada sekolah menengah kejuruan yg berada +200 meter dari tapak. Tapak ini memiliki luas : $+11500 \mathrm{~m} 2$, berbatasan Utara : Area Perkebunan, Timur : Area Perkebunan , Selatan : Jalan raya Banjarsari, Barat : Area Perkebunan.

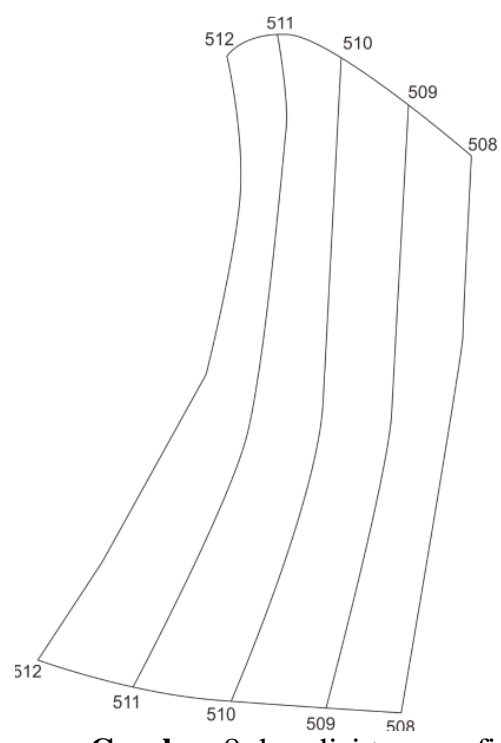

Gambar 8: kondisi topografi lahan Banjarsari

Alternatif Tapak ini memiliki topografi yang memiliki kemiringan paling landai dari dua tapak lainnya ke arah timur dan berada berada pada ketinggian 512-508 meter di atas permukaan laut. Berada pada area hutan sengon yang memiliki jenis tanah keras. Kemiringan antara $0-5$ derajat sehingga dapat dibilang lahan ini cukup datar dan hal ini membuat lahan cukup mudah unuk di ekplorasikan sebagai sebuah kantor dan fasilitas-fasilitas kantor kecamatan secara utuh dalam satu lokasi (lihat gambar 8).

Pada alternative tapak ini terdapat beberapa vegetasi yang cukup besar karena lahan ini merupakan perkebunan yang ditanami pohon yang menghasilkan kayu, sehingga menyerupai hutan. namun masih memungkinkan untuk di olah, vegetasi yang terdapat pada tapak beragam, antara lain :

- Pohon Pisang (Musa acuminata, M. balbisiana, dan M. ×paradisiaca)

- Pohon kelapa (Cocos nucifera)

- Pohon Sengon

Pada alternative tapak ini, kemungkinan sumur dalam untuk sumber airnya, dan sudah terdapat pembuangan air lingkungan secara langsung dari tapak.

Luas lahan yang ideal untuk perkantoran pemerintah dan bangunan Gedung pemerintah adalah 1.250 meter sesuai dengan Peraturan Presiden Republik Indonesia Nomor 73 Tahun 2011 Pasal 5 Tentang Pembangunan Bangunan Gedung Negara, pada peraturan dituliskan bangunan minimal 500 meter dengan asumsi KLB $60 \%$ sesuai dengan aturan setempat, sehingga didapatkan luasan minimal lahan adalah 1.250 meter. Pada alternative tapak ini, luasan lahannya sangat besar, yaitu 11.500 meter sehingga sangat memenuhi untuk dijadikan bangunan kantor kecamatan. Bahkan dapat dikembangan dengan optimal untuk kegiatan Bersama dan fasilitas-fasiitas lainnya. 
Tata guna lahan pada alternative tapak ini adalah sebagai perkebunan, dibuktikan dengan masih aktifnya lahan untuk fungsi tersebut. Namun bila dilihat secara Kawasan maka tata guna lahannya berdekatan dengan sekolahan dan disekitarnya masih kosong, sehingga masih memungkinkan digunakan sebagai perkantoran.

Pada alternative tapak ini terdapat pencapaian seara langsung ketapak. Karena lokasinya berada tepat dipinggir jalan raya windusari, sehingga memungkinkan untuk akses langsung. Jaringan jalan pada alternate tapak ini sangat baik karena berada tepat disisi jalan raya utama windusari, lebar jalanya sekitar 6 meter dan memudahkan untuk dikembangkan. Pencapaian pada alternative tapak ini bias secara langsung dan sangat mudah karena berada di lokasi yang datar dan di tepi jalan utama.

Pada alternative tapak ini, jarak ke pelayanan public lainnya sekitar $2-5 \mathrm{KM}$, namun disebelah tapak sekitar 100 meter dari tapak terdapat sekolahan dan kantor pemerintah serta kantor militer. Jarak kepermukiman penduduk sekitar 500 meter - $1 \mathrm{KM}$ dari lokasi tapak, cukup dekat namun lokasi ini masih cukup sepi dikarenakan bukan berada di pusat dari fasilitasfasilitas lainnya. Didepan tapak terdapat makam sehingga hal ini yang dimungkinkan sepi dari permukiman warga. Pada alternative tapak ini tidak terdapat fasilitas pendukung, untuk ke fasilitas yang sudah ada jaraknya antara $1-2 \mathrm{KM}$. Kecuali kantor militer dan sekolahan SMP ada sekitar 50 - 100 meter dari tapak.

Penilaian terhadap tapak ke-3 ini didapatkan hasil score sejumlah 45 dari nilai maksimal 55, dapat di prosentasikan yaitu sebesar $81 \%$ hasilnya (lihat tabel 4). Jika dilihat dengan prosentase scoring yang sudah ditentukan diatas, hasil scoring yaitu $81 \%$ yang berarti sangat layak. Hasil secara keseluruhan cukup dapat diinterpertasikan alternative tapak ini sangat layak.

Tabel 4: Tabel Perhitungan penilaian tapak 3

\begin{tabular}{|l|l|l|c|}
\hline No & \multicolumn{1}{|c|}{ Indikator } & \multicolumn{1}{|c|}{ Variabel } & $\begin{array}{c}\text { Score } \\
(\mathbf{1 - 5})\end{array}$ \\
\hline 1 & $\begin{array}{l}\text { Keadaan } \\
\text { geografis }\end{array}$ & Topografi & 5 \\
\hline & & Vegetasi & 2 \\
\hline 2 & Eksisting & Hidrologi & 3 \\
\hline & & Tata guna Lahan & 3 \\
\hline 3 & Lokasi & Akses menuju Lahan & 5 \\
\hline & & Jaringan jalan & 5 \\
\hline & & Pencapaian & 3 \\
\hline 4 & Fasilitas & $\begin{array}{l}\text { Jarak ke pelayanan public } \\
\text { lainnya }\end{array}$ & 4 \\
\hline & & Jarak ke penduduk & 4 \\
\hline & & Adanya fasilitas pendukung & 3 \\
\hline
\end{tabular}

Untuk mendapatkan kelebihan dan kekurangan maka akan mencoba menscorekan per variable, yan terdiri dari 4 variabel, yaitu : Keadaan geografis, eksisting, lokasi dan fasilitas. Maka didapatkan hasil sebagai berikut :

1. Keadaan geografis

Didapatkan total score 10 dari total 55, maka jika di posentasekan $18 \%$ hasil dari keadaan geografisnya yang terdiri dari indicator : Topografi, Vegetasi, Hidrologi

2. eksisting

Didapatkan total score 8 dari total 55, maka jika di posentasekan $14 \%$ hasil dari keadaan geografisnya yang terdiri dari indicator : Luas Lahan, Tata guna Lahan

3. Lokasi

Didapatkan total score 15 dari total 55, maka jika di posentasekan $28 \%$ hasil dari keadaan geografisnya yang terdiri dari indicator: Akses menuju Lahan, Jaringan jalan, Pencapaian

4. Fasilitas

Didapatkan total score 12 dari total 55, maka jika di posentasekan $21 \%$ hasil dari keadaan geografisnya yang terdiri dari indicator : Jarak ke pelayanan public lainnya, Jarak ke penduduk, Adanya fasilitas pendukung.

Kelebihan Aternatif tapak dari Variabel yang telah ditetapkan dan disimpulkan bahwa lokasi merupakan penentu utama dari scoring pemilihan tapak untuk kantor kecamatan, dibuktikan bahwa alternative 3 dapat score tertinggi dikarenakan dari segi lokasi ada pada urutan pertama. Sementara Fasilitas dan Geografis merupakan urutan selanjutnya dapat dibuktikan dengan alternative tapak 1 dan 2 juga memiliki urutan yang sama, yaitu fasilitas dulu baru keadaan geografis. Dan yan terakhir baru eksisting. Sedangkan pada alternative 1 Lokasi dan Eksisting memiliki score yang sama lihat tabel 5 .

Tabel 4: Tabel Perbandingan hasil penilaian tapak

\begin{tabular}{cccc}
\hline urutan & tapak 1 & tapak 2 & tapak 3 \\
\hline pertama & fasilitas & fasilitas & lokasi \\
kedua & keadaan & keadaan & fasilitas \\
& geografi & geografi & \\
ketiga & lokasi \& & lokasi & keadaan \\
& eksisting & & geografi \\
keempat & eksisting & & eksisting \\
prosentase & $49 \%$ & $67 \%$ & $81 \%$ \\
\hline
\end{tabular}

\section{KESIMPULAN}

Tapak yang tepat untuk dipilih dan dibangun kantr kecamatan Windusari. Studi ini merupakan scoring tiga alternative tapak yang dipilih oleh pihak Kecamatan Windusari untuk kemudian dpilih man ayang paling tepat. Hasil studi ini menunjukkan alternative tapak 3 memiliki score tertinggi dengan kategori sangat layak di 
angka $81 \%$. Sedangkan alternative kedua ada diurutan kedua yaitu $67 \%$ dan alternatif 1 ada diurutan ke tia dengan score $49 \%$.

Masing-masing tapak memiliki kelebihan dan kekurangan masing-masing, setelah di scoring berdasarkan variable dan indicator yang telah disusun berlandaskan teori dan regulasi maka didapatkan hasil maksimal pada alternative tapak 3 walaupun ada indicator yang masih memiliki angka rendah (tidak semua indicator memiliki nlai maksimal)

Hal lain yang bias disimpilkan adalah dari 4 variabel yaitu lokasi, keadaan geografis, eksisting dan fasilitas didapatkan bahwa lokasi merupakan penentu utama dari scoring pemilihan tapak untuk kantor kecamatan, dibuktikan bahwa alternative 3 dapat score tertinggi dikarenakan dari segi lokasi ada pada urutan pertama. Sementara Fasilitas dan Geografis merupakan urutan selanjutnya dapat dibuktikan dengan alternative tapak 1 dan 2 juga memiliki urutan yang sama, yaitu fasilitas dulu baru keadaan geografis. Dan yang terakhir baru eksisting. Sedangkan pada alternative 1 Lokasi dan Eksisting memiliki score yang sama.

\section{REKOMENDASI}

Rekomendasi jika hasil studi ini digunakan untuk memilih tapak dan membangun kantor kecamatan Windusari adalah sebagai berikut :

- Alternatif tapak 3 adalah tapak terpilih dengan score tertinggi, namun ada beberapa hal yang harus diperhatikan antara lain penyusunan tata guna lahan dan pada lokasi ini difugsikan sebagai area perkantoran, dikarenakan lokasinya yang strategis dan terletak dialan raya utama Windusari.

- Lahan yang saat ini mash terdapat pohon-poho yang dapat menghasilkan kayu sehingga jika meilih lahan ini, kayu tersebut dapat dimanfaatkan untuk bangunannya.

- Jika kecamatan ingin dibuat sebuah kantor dengan pengembangan publk space dan pariwisata sebaiknya memilih pada alternative tapak dikarenakan lkasi sangat berpotensi sebaga i lokasi wisata. Namun akses menuju lokasi harap dtinjau ulang dikarenakan pencapaian tidak bias secara langsung,akses tidak ada, serta jalan hanya jalan lingkungan dengan lebar 2 meter disetai topografi yang sangat curam.

\section{DAFTAR REFERENSI}

Aslaksen (1997) Universal design: Planning and Design for All, Cornel University accessed at http://digitalcommons.ilr.cornell.edu/gladnetcolle ct

Bungin, Burhan(2005) Metode Penelitian Kuantitatif. Jakarta : Prenadamedia
De Chiara, Joseph dan Hancock, John Hancock (2001) Time Saver Standar for BuildingTypes 4th edition,Mc Graw-Hill

Dumanski, (1997), Criteria and Indicator for Land Quality Management. In ITC Journal. 19973/4.243-247

Hakim, Maulana N, Cahyana, Rinda (2015) Pengembangan Sistem Informasi Geografis Untuk Memudahkan Pencarian Informasi Fasilitas Sosial Dan Lokasinya, Jurnal Algoritma Vol 12, No 1

Harani, Arnis Rochma, et al (2019) kontekstual lokasi tapak pada kecamatan srumbung magelang, MODUL vol 19 no 1, p19-24

Harsritanto, Bangun IR (2018) Urban Environment Development based on Universal Design Principles, E3S Web of Conferences 31, 09010

Harsritanto, Bangun IR (2018) Sustainable Streetscape Design Guideline based on Universal Design Principles, MATEC Web of Conferences 159, 01003

Harsritanto, Bangun IR, et al (2017) Universal design characteristic on themed streets, IOP Conf. Ser.: Earth Environ. Sci. 99012025

Pray, James Sturgis (1914) The Survey for a City Plan, 5 th annual conference of mayors and other city of Newyork

Sari, Vera Revina (1997) Perencanaan Lokasi Bangunan Negara, IAP

Sujarto, Djoko (1985) Beberapa Pengertian Tentang Perencanaan Fisik, Bhrata Karya Aksara

Sujarto, Djoko (2001) Pilihan Strategis : Suatu Pengambilan Keputusan dalam PErencanaan Wilayah dan Kota, Bandung : Institut Teknologi Bandung 